\title{
Perceptions of Owners on the Roles and Future of Bamboo-Tree Gardens in the Agricultural Landscape of the Upper Citarum Basin, West Java-Indonesia
}

\author{
Oekan S. Abdoellah ${ }^{*}$, Parikesit ${ }^{2}$, Satoru Okubo³, Susanti Withaningsih", \\ Kazuhiko Takeuchi ${ }^{5}$, Kosuke Mizuno ${ }^{6}$ \\ ${ }^{1}$ Institute of Ecology and Department of Anthropology, Faculty of Social and Political Sciences, \\ Padjadjaran University, Bandung, Indonesia \\ ${ }^{2}$ Institute of Ecology and Department of Biology, Faculty of Mathematics and Natural Sciences, \\ Padjadjaran University, Bandung, Indonesia \\ ${ }^{3}$ National Institute for Agro-Environmental Sciences, Tsukuba, Japan \\ ${ }^{4}$ Graduate Program on Environmental Studies and Institute of Ecology, Padjadjaran University, \\ Bandung, Indonesia \\ ${ }^{5}$ UNU Center, United Nations University, Tokyo, Japan \\ ${ }^{6}$ Center for Southeast Asian Studies, The University of Kyoto, Sakyo, Japan \\ Email: "oekan.abdoellah54@gmail.com
}

Received 15 July 2015; accepted 20 November 2015; published 23 November 2015

Copyright (C) 2015 by authors and Scientific Research Publishing Inc.

This work is licensed under the Creative Commons Attribution International License (CC BY).

http://creativecommons.org/licenses/by/4.0/

c) (†) Open Access

\begin{abstract}
We studied human perceptions on the management of bamboo-tree gardens in two villages with contrasting agroecological conditions in the upper Citarum basin. We undertook interviews to reveal perceptions on the tenure, function, and management strategies of multi-layered agroforest. Owners in a village located lower in the basin perceived the gardens more positively than those in an upland village, where market pressures were felt more keenly and for a longer period. There was not always a direct correlation between perceptions and behavior with respect to bamboo-tree garden management. However, we concluded that an understanding of human perceptions could provide valuable insight to the process of formulating strategies that might be effective in minimizing the conversion of bamboo-tree gardens to more intensive and less ecologically diverse agricultural systems. Specifically, since the villagers retained a strong cultural perception of the heritage value of the bamboo-tree gardens, they would likely be responsive to conservation efforts that increased the economic value of the gardens and reduced the opportunity cost of not converting them to production that is more intensive or other land uses.
\end{abstract}

"Corresponding author.

How to cite this paper: Abdoellah, O.S., Parikesit, Okubo, S., Withaningsih, S., Takeuchi, K. and Mizuno, K. (2015) Perceptions of Owners on the Roles and Future of Bamboo-Tree Gardens in the Agricultural Landscape of the Upper Citarum Basin, West Java-Indonesia. Agricultural Sciences, 6, 1333-1351. http://dx.doi.org/10.4236/as.2015.611128 
Keywords

Agroecosystem, Management Strategy, Cultural Values, Social Behavior, Traditional Practice

\section{Introduction}

Human activities are the primary drivers of dynamic agricultural systems, which in turn determine the structure and function of agroecosystems. Human activities in agroecosystems are the result of attitudes derived from a combination of ideas, motivations, and experiences [1]. Thus, it is necessary to integrate humans' activities, which are governed by human perceptions, value systems, cultural traditions, and socioeconomic activities into agroecosystems (see also Garcia-Llorente et al.) [2].

Achieving sustainable agroecosystems often depends on curtailing or managing human actions that either sustain or degrade the desired agroecosystems. Therefore, the human component of agricultural systems is central to their sustainability, and one of the most important aspects of the human component is perceptions of circumstances and environment. In other words, the human-agroecosystems relationship is influenced by the human worldview - a person's perception of the world and their place in it. Human perceptions shape the decision-making processes that lead to the actions that affect agroecosystems [3] and ultimately determine whether production and conservation goals are harmonized in the development of agricultural systems. Because of this intrinsic link between perceptions, decisions, and actions, gaining an understanding of human perceptions is a critical first step to achieve sustainable agriculture.

The structure and function of agroecosystems are closely linked to human perception. However, the relationship between perception and behavior is not always linear [4]-[7]. Various factors affect the relationship between perception and behavior, such as socioeconomic and cultural references that influence how individuals act [8]. On the other hand, ecological realities can also affect how farmers act with regard to agricultural practices, which in turn will form site-specific agroecosystem setting.

There has been insufficient research performed to reveal how traditional and modern societies exert their perceptions and values upon the ecosystems they live in and how they manage to practice sustainable environmental management. Yet, understanding the relationship between human and ecological phenomena is essential.

The evolutionary development of agroecosystems through the process of species introduction, selection, and substitution depend on how the rural people living within the system perceive their environment. To fulfill their daily basic needs, these people make use of almost any natural resources found in their surroundings. Whereas beneficial species and varieties will be maintained and promoted, less beneficial ones from human perspective will be neglected and replaced by more beneficial introduced species or varieties. The processes of introduction, selection, and substitution are likely to occur at a broad scale as well as a local scale. Consequently, anthropogenic forests are gradually transformed into more productive agricultural systems with lower biodiversity [9].

In Indonesia, agroecosystems play a crucial role in the national production system and are generally dominated by either wetland (paddy) or dryland agriculture. In the case of West Java, bamboo-tree gardens are among the most common traditional dryland agroecosystem. Bamboo-tree gardens are locally known as kebon tatangkalan [10] [11] and in parts of West Java as talun [12] [13], village gardens [14], or forest gardens [15]. They have a multi-layered structure predominantly composed of a variety of bamboos and tree species, and they tend to have been developed and maintained by rural farmers through many generations. This agroforest has been in existence before 1900s, but nowadays in much of Java, particularly West Java, the area of bamboo tree-gardens has been declining because of the increased use of more intensive market-oriented agricultural practices [11] [16].

In most cases, studies on the bamboo-tree garden system have focused on biophysical aspects of this element of the agricultural landscape [17]. The human dimension of the bamboo-tree garden system has not yet received much research attention.

This paper describes the perceptions of bamboo-tree garden owners in two villages of contrasting agroecological conditions within the upper Citarum basin with regard to the management of this traditional agricultural system. Perceptions relating to bamboo-tree garden management are important to the future sustainability of this socioeconomically and ecologically important traditional system. Parikesit et al. [11] pointed out the ecological 
importance of this agroforestry system by the fact that, nearly $80 \%$ of the bird species encountered in the study sites were found to use bamboo-tree garden patches as habitat. Some of the species found in bamboo-tree gardens are protected by the Indonesian law because of their rarity, ecological importance, and/or endemicity. In addition, bamboo-tree gardens also perform as a direct and indirect socioeconomic function such as providing food, fiber and fuelwood for local people [16].

We expect that the results of the study described in this paper could and should be used to guide policies on the conservation of bamboo-tree gardens in the upper Citarum basin. Conservation efforts are necessary not only because this landscape element has an important ecological role and high biodiversity [9]-[11], but also because many low income rural people depend on the bamboo-tree gardens for fuelwood as their only source of energy [9] [16].

\section{Methods}

\subsection{Study Site}

We selected two villages with contrasting agroecological characteristics in the upper Citarum basin: Wangisagara and Sukapura. Both villages are on the Citarum River that runs approximately $350 \mathrm{~km}$ from its source on Mount Wayang north to the Java Sea (north of Jakarta). The river is a major water resource in the region and three large reservoirs have been constructed along it.

Wangisagara village is located on gentle slopes that range in altitude from 800 to $850 \mathrm{~m}$ above sea level (asl), whereas Sukapura village is on steeper land ranging in altitude between 950 and $1250 \mathrm{~m}$ asl. The difference in altitude results in a considerable difference in climate between the two villages. The mean annual rainfall in Wangisagara ranged from 1500 to $2500 \mathrm{~mm}$ with minimum daily temperature in December and January between $20^{\circ} \mathrm{C}-25^{\circ} \mathrm{C}$ and maximum between $25^{\circ} \mathrm{C}-30^{\circ} \mathrm{C}$. In Sukapura, the mean annual rainfall was considerably greater at 2000 to $3000 \mathrm{~mm}$, and the daily minimum temperature in December and January was lower at $15^{\circ} \mathrm{C}-20^{\circ} \mathrm{C}$ with the maximum ranging from $22^{\circ} \mathrm{C}$ to $28^{\circ} \mathrm{C}$ (data obtained from the Regional Office of Meteorology and Geophysics). Other general characteristics of the study villages are summarized in Table 1.

\subsection{Sampling Design}

Prior to the selection of respondents for the interview survey, a full census of bamboo-tree garden owners in both villages undertaken at the rukun tetangga (RT) level was analyzed, since there were no formal records on bamboo-tree garden ownership. An RT headed by an elected chief is the smallest administrative unit within village administration. Each RT usually consists of 30 to 40 households, depending on the total number of households and the area of the village. The census revealed that only a small percentage of the households owned bamboo-tree gardens. Only 68 households owned bamboo-tree gardens in Wangisagara (3.30\%) and 52 households in Sukapura (2.46\%), the bamboo-tree owners in the two villages were all men.

The required number of respondents was determined by the following formula [18]:

$$
n=N \cdot Z^{2} \cdot p \cdot(1-p) / N \cdot d^{2}+Z^{2} \cdot p \cdot(1-p)
$$

where $n$ = number of respondents, $N=$ number of households in each study village, $Z$ = the value of the normal distribution (1.96) for a reliability level of $0.95, p=$ the highest possible proportion (0.5), and $d=$ the sampling error (0.1).

Using the above formula, 36 households in Wangisagara and 30 households in Sukapura were randomly selected. In addition to the present owners, interviews were also carried out with former owners if they were identified. Unfortunately, there was no formal record of ownership change, so only nine previous owners were interviewed in Sukapura and five in Wangisagara.

\subsection{Data Collection}

The data were collected based on structured interviews with randomly selected bamboo-tree garden owners in the two villages. To determine the owners' perceptions of their gardens, we asked them 56 questions using the semantic differential technique based on arguments as follows:

- Similar socio-cultural background of owners in the two villages;

- Same (local) knowledge with regard to bamboo-tree garden cultivation practices; 
Table 1. General characteristics of the study villages (source: official village records in 2012).

\begin{tabular}{|c|c|c|}
\hline Description & Wangisagara & Sukapura \\
\hline \multicolumn{3}{|l|}{ Distance from major urban centers $(\mathrm{km})$} \\
\hline From subdistrict capital & 4 & 7 \\
\hline From district capital & 31 & 39 \\
\hline From province capital & 41 & 52 \\
\hline \multicolumn{3}{|l|}{ Population data } \\
\hline Number of inhabitants & 13,344 & 13,332 \\
\hline Number of households & 3795 & 4290 \\
\hline \multicolumn{3}{|l|}{ Agricultural land area $($ ha $)$} \\
\hline Rice field & 129.5 & 15.0 \\
\hline Upland field & 48.5 & 205.1 \\
\hline Settlement (including homegardens) & 46.5 & 294.0 \\
\hline \multicolumn{3}{|l|}{ Income source activities (\%) } \\
\hline On-farm & 42.6 & 81.6 \\
\hline Off-farm & 57.4 & 18.4 \\
\hline \multicolumn{3}{|l|}{ Education status (\%) } \\
\hline No formal education & 13.7 & 6.1 \\
\hline Elementary school & 44.5 & 80.4 \\
\hline Junior high school & 33.5 & 9.0 \\
\hline High school & 7.2 & 3.7 \\
\hline Higher education & 1.1 & 0.8 \\
\hline
\end{tabular}

- Individual preference with regard to decision making process in bamboo-tree garden management.

For each question, the answer was scored from 1 to 7, ranging from very negative (1) to very positive perception (7). The score for every answer inevitably contained an element of subjectivity on the part of interviewers. Therefore, a probing questioning technique was used during the interviews. Where doubtful scoring occurred, the interviewer had to return to the respondent to clarify ambiguous answers. A single interview could last more than 2.5 hours. Information on agricultural land ownership and social parameters such as education level and main occupation were also collected.

The questionnaire was divided into several categories related to the owner's perceptions of their bamboo-tree garden or, in some questions, bamboo tree-gardens in the village (Table 2). These categories were (A) garden ownership; (B) the socioeconomic, cultural, and ecological functions of the garden; (C) management of the garden; (D) recognition of any decline in bamboo-tree gardens in the village and causes for that decline; and (E) the outlook for preservation of the gardens. Some of these categories consisted of several subcategories (Table 2). For example, the first category, about the general attitude to owning a garden, consisted of three subcategories pertaining to socioeconomic status, cultural meaning, and economic benefit. The 56 questions were classified into each subcategory, and 33 major questions were chosen to reflect the major aspects of each category or subcategory. The codes used for the 33 major questions and a brief explanation of each major question are shown in Table 2. The remaining 23 questions were to provide supporting information related to the major questions and/or additional perceptions of the respondents.

Semi-structured interviews were also carried out with former owners and other relevant informants, such as the village leader, local farmers, and fuelwood gatherers, to cross check the answers given to particular questions by bamboo-tree garden owners. Secondary data were collected from various sources including previous 
Table 2. Structure of the main questionnaire (33 questions) arranged into five categories.

Category Contents Number of

A. Perceptions on the general meaning of owning a bamboo-tree garden

A1 Socioeconomic status of the owners considered as rich (A1-1) and respected (A1-2)

A2 Importance of maintaining culture/tradition as an inherited family asset (A2-1) and as inheritance to descendants (A2-2)

A3 Economic benefit obtained by selling products

B. Perceptions on the functions of bamboo-tree gardens

B1 Economic functions as source of income (B1-1), family savings (B1-2), and asset to leave as inheritance (B1-3)

B2 Social functions of providing free fuelwood to other villagers in form of dead trees (B2-1) and branches (B2-2)

B3 Ecological functions as providing wildlife habitat (B3-1), recharging and storing water (B3-2), preventing soil erosion (B3-3), and a place for tree growing (B3-4)

C. Perceptions on bamboo-tree garden management

Frequency of actual management activities such as fertilizer application (C1-1), control of diseases and pests (C1-2),

C1 pesticide input (C1-3), manual weeding (C1-4), maintaining and regenerating trees (C1-5), and making terraces (C1-6)

C2 Knowledge of management techniques for improving the productivity of the garden itself

C3 Maintenance requirements as financial (C3-1) and time (C3-2) costs

D. Perceptions on bamboo-tree garden decline and causal factors

D0 Recognition that the area of bamboo-tree gardens in the village is declining

D1 Perceived reason for land conversion is to create cash-crop gardens (D1-1) or settlements and home gardens (D1-2)

D2 Perceived cause of conversion is the economic benefit of land conversion to other uses

D3 Perceived cause of conversion is the lack of government concern and support

E. Perceptions on the importance of bamboo-tree gardens and ways of preserving them

E0 Willingness to preserve bamboo-tree gardens in the village

E1 Necessity of economic improvement by more intensive management (E1-1) and increasing the market value of products (E1-2)

E2 Necessity of supporting programs such as providing suitable tree seeds/seedlings (E2-1) and reducing land tax (E2-2)

studies conducted at the present study sites. Data on the general characteristics of the villages were obtained from the village office.

\subsection{Data Analysis}

We performed principle components analysis (PCA) of the perception scores. Eight respondents from Wangisagara did not answer all of the questions, so the answers of 58 respondents (28 in Wangisagara and 30 in Sukapura) were available for analysis. The respondents' scores on each PCA axis were correlated with external factors such as the area of agricultural land owned and education level obtained to determine causal relationships between perceptual rankings and external factors. Kendalltau rank correlations, a nonparametric measure of the degree of correspondence between rankings, were also calculated.

The trends in respondents' perceptions obtained from the PCA differed between Wangisagara and Sukapura. We tested differences in perceptions of the bamboo-tree garden owners between the two villages using the Mann-Whitney $U$-test on the responses to the 33 major questions as well as to some of the supporting questions. All statistical analyses were performed using SPSS 10.0 (SPSS Inc., Chicago, Illinois, USA). 


\section{Results}

\subsection{Ownership of Agricultural Land}

There was no significant difference in the size of bamboo-tree gardens between Wangisagara and Sukapura (Table 3). The number of owners and size of upland fields of vegetable cash-crop fields and kebun palawija, which is a mixed cropping system of inter-planting a number of annual crops in the same field at the same time, and usually consisted of maize, cassava, sweet potato, and peanut, were higher in Sukapura $(P<0.01)$, whereas Wangisagara has more owners and greater area of paddy fields $(P<0.01)$.

\subsection{Relation between Respondents Profile and Some Biophysical Aspects of Bamboo-Tree Gardens}

The principle components analysis (PCA) on the data set with 33 variables and 58 samples yielded five principle components or axes that had eigenvalues $>2$. The eigenvalues for the first to the fifth axis, in order, were 5.25, 4.31, 2.90, 2.41, and 2.23 (Table 4). Together, these five axes accounted for more than half the total variance (51.8\%). Factor loadings for each variable or question in the five axes calculated by PCA are shown in Table 4 .

Correlations between the five principle component scores and agricultural landownership are shown in Table 5. The size of bamboo-tree gardens was significantly positively correlated with the first axis and negatively with the third axis. The size of paddy fields was significantly positively correlated with the first axis and negatively

Table 3. Area of agricultural land owned by the respondents in Wangisagara and Sukapura by primary use and statistical comparison of the two samples. Respondents consisted of both bamboo-tree garden owners and other key people.

\begin{tabular}{|c|c|c|c|}
\hline \multirow{2}{*}{ Type of agricultural land $\left(\mathrm{m}^{2}\right)$} & \multicolumn{2}{|c|}{ Villages } & \multirow{2}{*}{$\begin{array}{c}\text { Statistical } \\
\text { significance } \\
\text { (Mann-Whitney } \\
U \text {-test) }\end{array}$} \\
\hline & $\begin{array}{l}\text { Wangisagara } \\
\quad(n=36)\end{array}$ & $\begin{array}{l}\text { Sukapura } \\
(n=30)\end{array}$ & \\
\hline \multicolumn{4}{|l|}{ Bamboo-tree garden } \\
\hline Average of all respondents & 1346 & 1595 & N.S. \\
\hline Range & $140-7000$ & $56-8400$ & - \\
\hline \multicolumn{4}{|l|}{ Upland fields } \\
\hline Average of all respondents & 107 & 2402 & ** \\
\hline Range & $0-2100$ & $0-30,000$ & - \\
\hline Average of owners only & $\begin{array}{l}2450 \\
(n=3)\end{array}$ & $\begin{array}{c}5542 \\
(n=13)\end{array}$ & $* *$ \\
\hline \multicolumn{4}{|l|}{ Paddy field } \\
\hline Average of all respondents & 3766 & 1866 & ** \\
\hline Range & $0-20,000$ & $0-16,800$ & - \\
\hline Average of owners only & $\begin{array}{c}4237 \\
(n=32)\end{array}$ & $\begin{array}{c}2800 \\
(n=20)\end{array}$ & $* *$ \\
\hline \multicolumn{4}{|l|}{ Home garden } \\
\hline Average of all respondents & 290 & 505 & ** \\
\hline Range & $0-1400$ & $0-2100$ & - \\
\hline Average of owners only & $\begin{array}{c}299 \\
(n=35)\end{array}$ & $\begin{array}{c}541 \\
(n=28)\end{array}$ & ** \\
\hline
\end{tabular}

${ }^{* *} P<0.01 ;$ N.S. indicates no significant difference; - indicates no test performed. 
Table 4. Factor loadings of each variable (question) for five PCA axes.

\begin{tabular}{|c|c|c|c|c|c|}
\hline \multirow{2}{*}{ Variable $^{\mathrm{a}}$} & \multicolumn{5}{|c|}{ Factor loadings of each PCA axis (eigenvalue of each axis) } \\
\hline & PCA $1(5.25)$ & PCA 2 (4.31) & PCA $3(2.90)$ & PCA 4 (2.41) & PCA $5(2.23)$ \\
\hline A1-1 & 0.25 & -0.51 & -0.55 & -0.06 & -0.23 \\
\hline A1-2 & 0.33 & -0.50 & -0.55 & -0.06 & -0.31 \\
\hline A2-1 & 0.33 & 0.08 & 0.32 & 0.25 & -0.42 \\
\hline A2-2 & 0.30 & 0.10 & 0.05 & -0.02 & -0.40 \\
\hline A3 & 0.44 & -0.01 & -0.49 & -0.19 & 0.17 \\
\hline B1-1 & 0.44 & 0.33 & -0.24 & -0.24 & 0.07 \\
\hline B1-2 & 0.67 & -0.13 & 0.44 & -0.22 & 0.15 \\
\hline B1-3 & 0.33 & -0.07 & -0.40 & 0.21 & 0.14 \\
\hline B2-1 & 0.05 & 0.62 & 0.23 & -0.30 & -0.31 \\
\hline B2-2 & 0.12 & 0.61 & 0.25 & -0.32 & -0.33 \\
\hline B3-1 & 0.37 & -0.28 & 0.12 & -0.25 & 0.39 \\
\hline B3-2 & 0.58 & -0.02 & -0.07 & -0.56 & 0.03 \\
\hline B3-3 & 0.56 & -0.13 & -0.12 & -0.37 & 0.08 \\
\hline B3-4 & 0.54 & -0.15 & 0.25 & 0.26 & 0.34 \\
\hline C1-1 & 0.54 & 0.07 & -0.12 & 0.34 & -0.28 \\
\hline C1-2 & 0.46 & 0.13 & -0.21 & 0.29 & -0.18 \\
\hline C1-3 & 0.37 & 0.58 & 0.03 & 0.39 & -0.03 \\
\hline C1-4 & 0.44 & 0.54 & 0.01 & 0.20 & 0.03 \\
\hline C1-5 & 0.34 & 0.43 & -0.02 & 0.51 & 0.15 \\
\hline C1-6 & -0.14 & 0.14 & -0.15 & 0.18 & 0.28 \\
\hline C2 & 0.58 & 0.38 & -0.27 & 0.16 & -0.11 \\
\hline С3-1 & 0.08 & -0.40 & -0.20 & 0.52 & -0.18 \\
\hline С3-2 & 0.45 & 0.67 & 0.03 & -0.04 & -0.12 \\
\hline D0 & 0.11 & -0.26 & 0.34 & -0.29 & -0.50 \\
\hline D1-1 & -0.27 & 0.59 & 0.11 & 0.13 & 0.35 \\
\hline D1-2 & 0.07 & -0.17 & 0.24 & 0.23 & -0.23 \\
\hline D2 & -0.19 & 0.33 & -0.22 & -0.01 & 0.50 \\
\hline D3 & 0.30 & -0.08 & 0.41 & -0.14 & 0.28 \\
\hline E0 & 0.48 & 0.07 & 0.21 & -0.19 & 0.21 \\
\hline E1-1 & 0.61 & -0.08 & -0.39 & -0.12 & 0.26 \\
\hline E1-2 & 0.52 & -0.51 & 0.39 & 0.17 & 0.03 \\
\hline E2-1 & 0.47 & -0.41 & 0.58 & 0.18 & 0.15 \\
\hline E2-2 & 0.07 & -0.44 & 0.25 & 0.33 & 0.15 \\
\hline
\end{tabular}

${ }^{\mathrm{a}}$ See Table 2 for the abbreviations of variables. 
Table 5. Kendall's correlation coefficients between PCA axes and the area of agricultural lands owned by each respondent.

\begin{tabular}{|c|c|c|c|c|c|c|c|c|c|}
\hline & (i) & (ii) & (iii) & (iv) & (v) & (vi) & (vii) & (viii) & (ix) \\
\hline PCA axis 1 (i) & 1.000 & - & - & - & - & - & - & - & - \\
\hline PCA axis 2 (ii) & 0.028 & 1.000 & - & - & - & - & - & - & - \\
\hline PCA axis 3 (iii) & -0.080 & 0.049 & 1.000 & - & - & - & - & - & - \\
\hline PCA axis 4 (iv) & 0.027 & 0.045 & -0.049 & 1.000 & - & - & - & - & - \\
\hline PCA axis $5(\mathrm{v})$ & 0.003 & 0.041 & 0.016 & 0.066 & 1.000 & - & - & - & - \\
\hline Area of bamboo-tree gardens (vi) & $0.203^{*}$ & 0.177 & $-0.201^{*}$ & 0.108 & 0.048 & 1.000 & - & - & - \\
\hline Area of upland arable lands (vii) & -0.033 & 0.170 & 0.012 & 0.084 & $0.262^{*}$ & -0.104 & 1.000 & - & - \\
\hline Area of paddy fields (viii) & $0.239^{*}$ & $-0.217^{* *}$ & -0.113 & -0.043 & -0.133 & $0.268^{* *}$ & $-0.282^{* *}$ & 1.000 & - \\
\hline Area of home gardens (ix) & -0.100 & 0.136 & 0.023 & -0.095 & 0.125 & 0.122 & 0.140 & -0.036 & 1.000 \\
\hline
\end{tabular}

with the second axis. The area of paddy fields was significantly positively correlated with the area of bamboo-tree gardens and negatively correlated with the area of upland fields. The latter correlation is understandable because respondents who owned paddy fields were predominantly in Wangisagara where there were relatively few upland fields (Table 3).

Figure 1(a) shows the factor loadings for the 33 questions and the principle component scores of the 58 respondents for the first and second components although the cumulative explanation of variance was about $30 \%$ for these two components. The scatter patterns of the respondents were different for the two villages; respondents from Wangisagara had larger scores on the first axis and smaller scores on the second axis than those of Sukapura (Figure 1(b)).

Although the difference in the scores of the two villages for the first axis was not significant $(P=0.054)$, the scores of Wangisagara tended to be higher, and there was a significant difference between the villages for the second axis $(P<0.01)$. There were no significant differences for the third and fourth axes $(P=0.99$ and 0.84 , respectively), but the fifth axis was correlated with the size of upland fields, where Sukapura had higher scores $(P<0.01)$.

Regarding the relationship between social parameters (such as main occupation and educational level) and principle component scores for each respondent, there was no significant relationship for the three educational levels: no education, completed primary school only, and completed higher school (U-test with Bonferroni corrections).

The PCA scores of respondents whose main occupation was farmer were significantly higher on the second PCA axis than those whose main occupation was non-farmer $(P<0.01)$. Since all seven non-farmers belonged to the village of Wangisagara, we compared the relationship between the scores of the second axis with occupations of respondents of that village only; there was no difference. This means that the perceptions of respondents were not influenced by either educational level or main occupation.

Along the first axis of correlation with the area of bamboo-tree gardens, perceptual categories such as economic and ecological functions of the gardens (B1 and B3), management knowledge to improve productivity of the gardens (C2), and willingness to preserve the gardens, especially with economic improvements (E0 and E1), had higher values (Figure 1(a)). The axis reflected generally positive perceptions on the existence of the gardens and indicated an economic dependency on the gardens.

Regarding the second axis, perceptual categories having higher values were those that referred to management frequency, especially of the more intensive activities such as pesticide input, weeding, and tree management (C1-3, C1-4, and C1-5). Other categories with higher scores included the amount of time spent on maintenance (C3-2), social functions (B2), and awareness of the decline in the garden through conversion to cash crops (D1-1). Scores with lower values were for socioeconomic status of the garden’s owner (A1), maintenance cost 


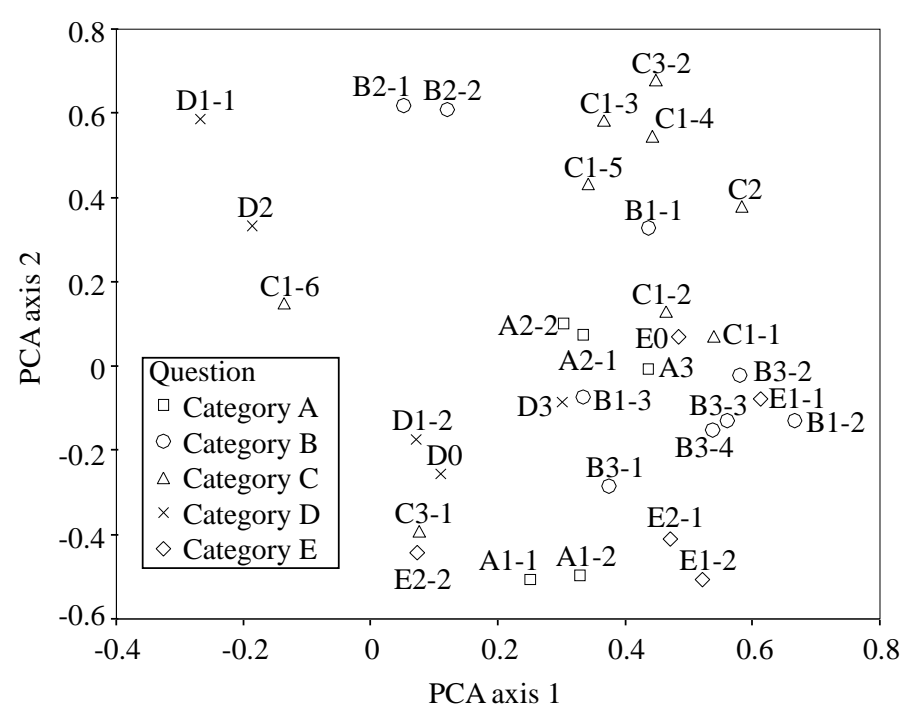

Legends:

PCA axis 1 represents: B1, B3, C2, E0, E1 (see Table 2 for abbrevation). PCA axis 2 represents: C1-3, C1-4, C1-5, C3-2, B2, D1-1, A1, C3-1, E1-2, E2 (see Table 2 for abbrevation)

(a)

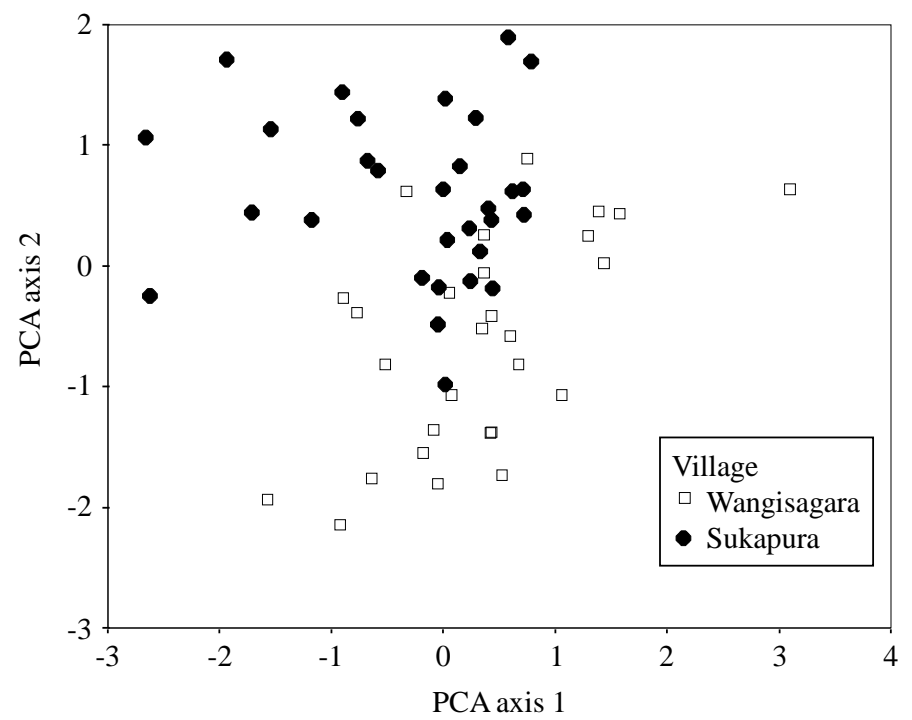

(b)

Figure 1. Scatter plots of (a) factor loadings of 33 questions and (b) principle component scores in two dimensions from the results of PCA. The key to question codes is shown in Table 2 of this paper.

(C3-1), need for marketing support to increase produce values (E1-2), and need for governmental support programs (E2) (Figure 1(a)). The second axis would therefore indicate intensification of the management of gardens. Respondents who had higher scores along the axis presumably managed their own gardens intensively, while those who had lower scores were likely to depend on sources of income other than their bamboo-tree garden.

For the third axis, which was significantly negatively correlated with the area of bamboo-tree garden, the questions with the five highest factor loadings were E2-1, B1-2, D3, E1-2, and D0, whereas the five lowest were A1-1, A1-2, A3, B1-3, and E1-1 (Table 4). Since there were positive perceptions on garden ownership in a negative direction, the axis explained the degree of negative perception for social and economic categories. For the 
fourth axis, the five highest categories were C3-1, C1-5, C1-3, C1-1, and E2-2, whereas the five lowest were B3-2, B3-3, B2-2, B2-1, and D0 (Table 4).

The association of perceived garden decline with positive perceptions on frequent management activities or with positive perceptions on social and ecological functions could indicate a perceptual contrast between whether the garden is seen as a part of nature or a part of the agricultural system. Finally for the fifth axis, which was significantly positively correlated with the area of upland fields, the five highest perceptual categories were D2, B3-1, D1-1, B3-4, and D3, whereas the five lowest were D0, A2-1, A2-2, B2-2, and B2-1 (Table 4).

Considering that the respondents of Sukapura had significantly higher scores on this axis than Wangisagara, it would appear to explain a perceptual difference. The farmers in Sukapura appear to recognize and accept a general garden decline for economic reasons, whereas those in Wangisagara appear to be alarmed by the decline because of the gardens' longstanding role for subsistence and particular social functions.

\subsection{Comparison of Perceptions between Sukapura and Wangisagara}

\subsubsection{Perceptions on Ownership}

The responses to the two questions probing the self-perception of wealth and social status of bamboo-tree garden owners had consistent factor loadings on each axis (Table 4, Figure 1(a) for the first 2 PCA axes). For both questions, the mean values of the responses were higher in Wangisagara than in Sukapura $(P<0.01$; A1-1 and A1-2 in Figure 2). This difference suggests that the owners in Wangisagara village had more positive perceptions on the value of bamboo-tree gardens as an important asset indicative of their socioeconomic status within the village. Their perception was also confirmed by direct observation of their material possessions during the interviews and statements from key informants that bamboo-tree gardens are usually owned by families of the property owners of their village for generations.

From the perspective of traditional and cultural perceptual categories, respondents in both villages had strong positive perceptions of the bamboo-tree garden as an important family asset inherited from their ancestors (A2-1) and that they in turn should leave as an inheritance to their descendants (A2-2). On the latter question, the score was higher in Wangisagara $(P<0.05$; A2-1 in Figure 2).

The income from the gardens in both villages was not large enough for most respondents to accumulate savings. Despite this, owners in both villages still had positive perceptions about the economic benefits of their

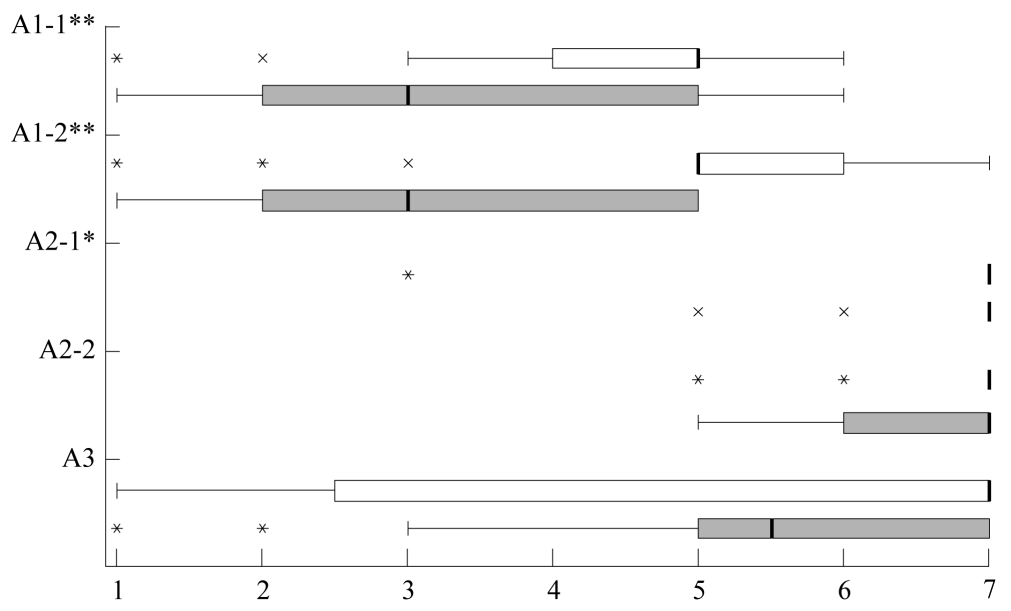

Figure 2. Boxplots of perceptual ranks (from 1 to 7) for the five questions in perceptual category A (general meaning of owning a bamboo-tree garden) for each village: Wangisagara = empty boxes and Sukapura $=$ shaded boxes. Boxes extend from the top of the first quartile to the top of the third quartile of the data range, and the median is shown as a line across the box. Whiskers are 1.5 times the box length and outliers between the end of the whiskers and 2.0 times the box length are indicated by an asterisk; outliers more than 2.0 times the box length are indicated by a cross. The question codes are shown in Table 2. A letter on a question code indicates a statistically significant difference between the two villages: ${ }^{* *} P<0.01 ;{ }^{*} P<0.05$. 
bamboo-tree gardens (A3 in Figure 2). Moreover, all respondents regardless of village provided a rank of seven (extremely important) to a supporting question about whether the amount of garden products was sufficient for their own consumption needs. The economic importance of owning the gardens was particularly well recognized in relation to subsistence. However, interviews with some key informants suggested that the owners in Sukapura associated the economic benefits of bamboo-tree gardens with the land itself rather than the products of the bamboo-tree garden. They also stated, prior to the 1970s, when inputs for agricultural production were not as intensive as they are now and the land-use was not as fragmented, bamboo-tree gardens played an important income-generation role for the owners.

\subsubsection{Perceptions on Functional Aspect of Bamboo-Tree Garden}

Although Sukapura respondents ranked the importance of the garden as an income source higher (B1-1), the difference between the villages was not significant (Figure 3). In contrast, even though respondents from both villages had positive responses to questions B1-2 and B1-3, which were related to the garden's importance as an economic asset as an inheritance to descendants, Wangisagara respondents' rankings were significantly higher ( $P<0.01$ and $P<0.05$, respectively; Figure 3 ). In accordance with perceptions on the general meaning of owning a garden, the economic function of the garden was perceived as an important family asset and heritage rather than as an income source in both villages.

Respondents also displayed positive perceptions about the social functions provided by their own garden. Although there was no significant difference between the two villages in the perceptual rankings of allowing other villagers to collect dead trees and branches for fuelwood (questions B2-1 and B2-2; Figure 3), the answers did vary. For Wangisagara respondents, the answers to the two questions were both significantly negatively correlated with the total area of arable land owned (excluding the bamboo-tree garden) (Kendall's correlation coefficient $r=-0.26, P<0.05$ for B1-1 and $r=-0.27, P<0.05$ for B1-2). This indicates that respondents who relied

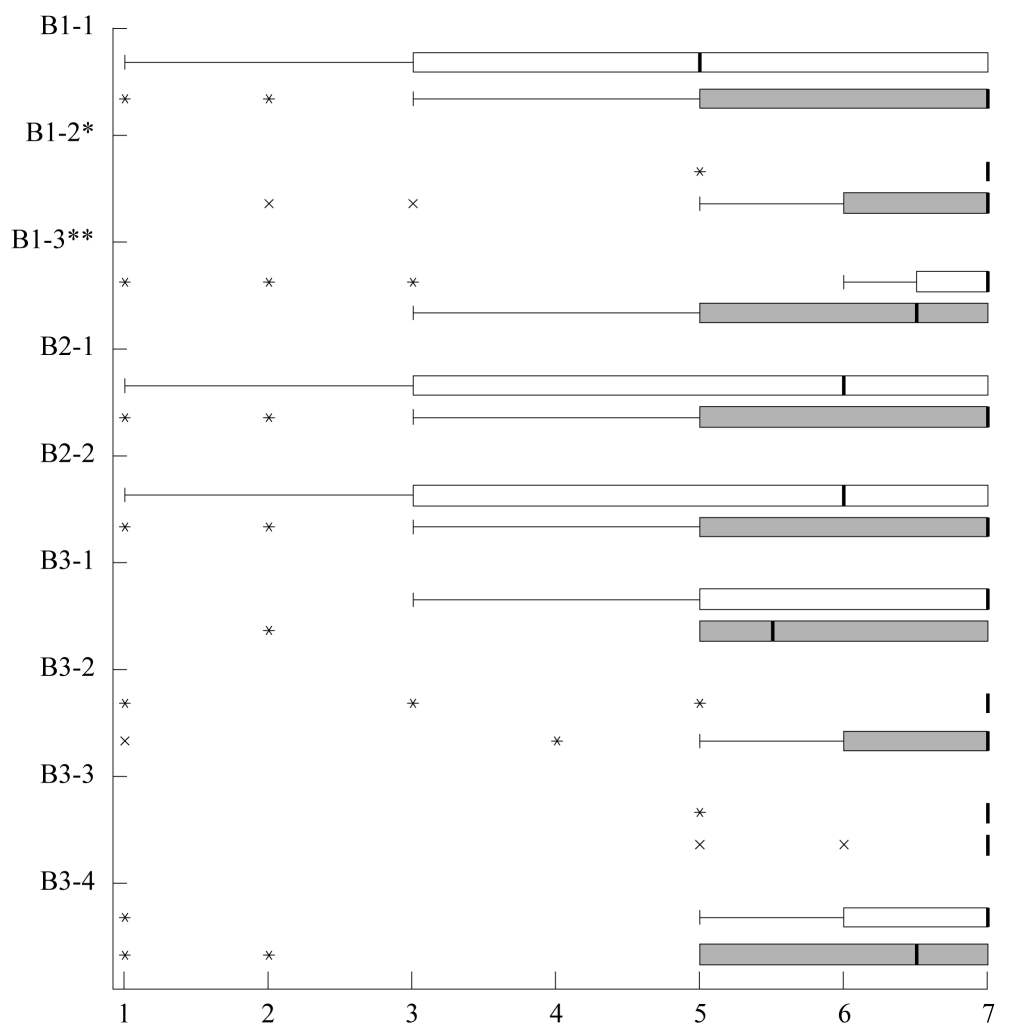

Figure 3. Boxplots of perceptual ranks for the nine questions in perceptual category B (functions of bamboo-tree gardens) for each village: Wangisagara $=$ empty boxes and Sukapura $=$ shaded boxes. See Figure 2 for legends and Table 2 for questions. 
primarily on the garden for income viewed the provision of free fuelwood to other villagers as detrimental to their own incomes. This tendency was not observed in Sukapura. That the respondents of Wangisagara rejected their garden's social function of providing fuelwood for others was noteworthy since they also perceived that the owners of gardens hold positions of respect within the village community.

Figure 3 shows that most respondents in both villages perceived the ecological functions of bamboo-tree gardens very positively. Although there were no significant differences between the two villages in the answers to questions B3-1 to B3-4, the strength of positive perception seen in the responses to all four questions was slightly higher in Wangisagara. The tangible ecological benefits of bamboo-tree gardens, such as preventing soil erosion and water storage (B3-2 and B3-3), were perceived more positively in both villages. These functions may be important in bamboo-tree garden patches located in steeper areas or near water springs. Therefore, the majority of respondents saw it as important to plant new trees in the bamboo-tree garden (B3-4). However, in response to a supporting question about planting new trees, most owners admitted that they only do it when space is available, usually after a tree has fallen.

\subsubsection{Perceptions on Management}

Most respondents in both villages performed some management activities (C1-1 to C1-6 in Figure 4). Of the six types of activities, fertilizer application (C1-1) and disease and pest control (C1-2) were very rare in both villages, although fertilizer application was significantly less frequent in Sukapura than Wangisagara $(P<0.05$; Figure 4). Consistent with these results, supporting questions revealed that the owners in Sukapura did not regard fertilizer application or pest and disease control as important (the average values were 1.87 and 1.33, respectively, where rank 1 = not important at all and rank 7 = extremely important). However, about $40 \%$ of Wangisagara respondents indicated that such management activities were important (3.34 and 2.67), and the differences between the two villages were significant $(P<0.05$ and $P<0.01)$.

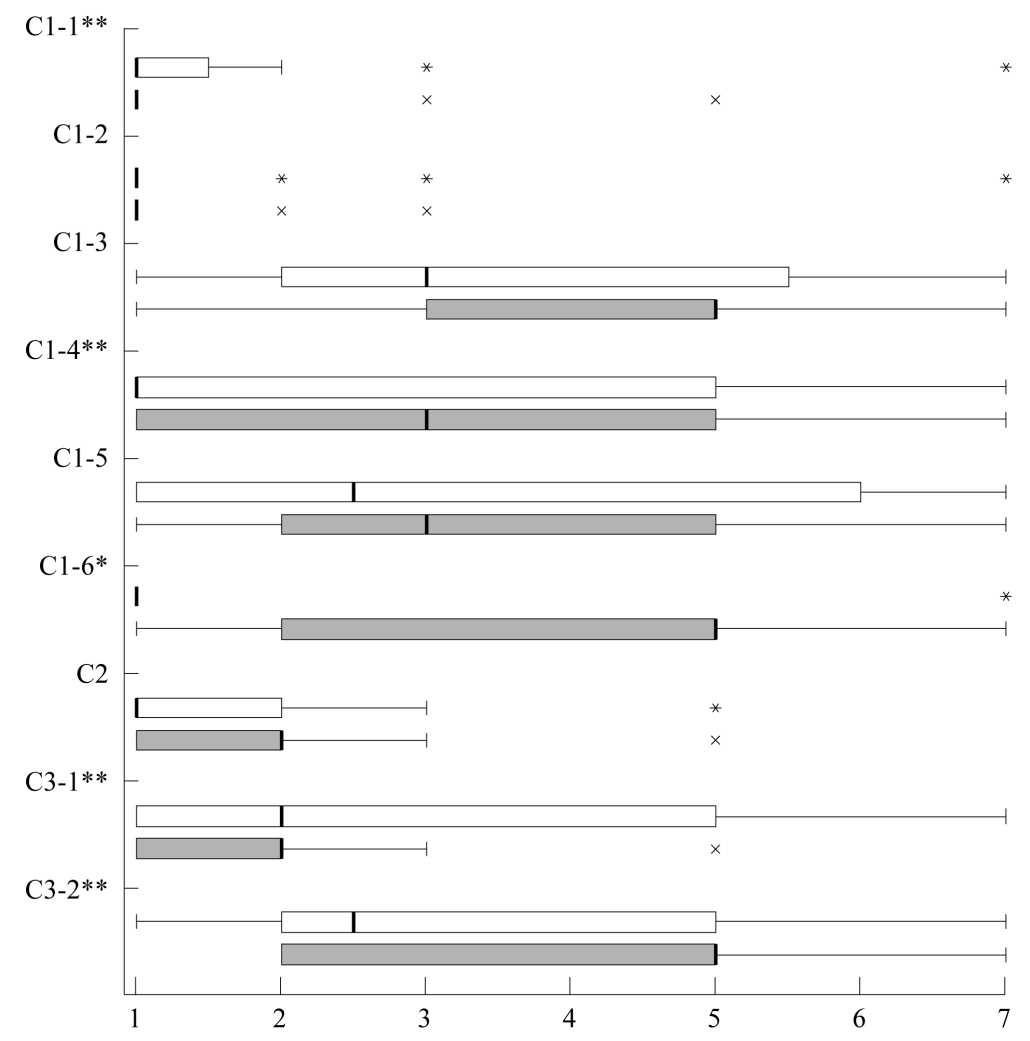

Figure 4. Boxplots of perceptual ranks for the nine questions in perceptual category C (bamboo-tree garden management) for each village: Wangisagara = empty boxes and Sukapura = shaded boxes. See Figure 2 for legends and Table 2 for questions. 
Regarding the more intensive management activities of using pesticides (C1-3), weeding (C1-4), and maintaining trees (C1-5), the respondents of Sukapura tended to apply them more frequently than those of Wangisagara (Figure 4), but the difference was only significant for weeding $(P<0.05)$. Responses to the frequency of making terraces displayed a different trend to the other management questions in the PCA factor loadings; the respondents of Sukapura had significantly higher values than those of Wangisagara $(P<0.01$; Figure 4$)$. Moreover, in response to a supporting question on the importance of making terraces, about $50 \%$ of respondents in Sukapura answered very important, whereas only $20 \%$ in Wangisagara gave the same answer and about $70 \%$ answered not important at all. The difference probably reflects the fact that gardens in Sukapura were located on steeper slopes than in Wangisagara.

Question C2 dealt with technical knowledge to improve productivity of the gardens. Most respondents in both villages answered very negatively, and there was no significant difference between the answers from villages, indicating that they believed the garden could not be as productive as other agricultural land like rice field and vegetable garden (Figure 4).

The two questions about management costs also reflected perceptual differences between the two villages. Question C3-1 asked whether the cost, including taxes, of managing the garden is too high, and C3-2 asked whether the owners had adequate time available to maintain the garden. The answers from Wangisagara respondents were significantly higher to C3-1 $(P<0.05$; Figure 4$)$ and significantly smaller to C3-2 $(P<0.05$; Figure 4). This indicates that the respondents of Wangisagara felt both financial and time constraints for managing their own gardens. These results contradicted our expectations. We assumed that the respondents of Sukapura would be more likely to display a preference for allocating their capital and time to their larger holdings of productive arable land than to the bamboo-tree gardens.

\subsubsection{Perceptions on Factors That Cause the Decline of Bamboo-Tree Gardens}

The respondents of both villages indicated that they perceived the area of gardens in the village to be decreasing (D-0), and this perception was significantly stronger in Wangisagara ( $P<0.01$; Figure 5); more than $90 \%$ of respondents ranked this perception above 4 , whereas only $70 \%$ of Sukapura respondents ranked the perception above 4 . Of the respondents who answered that the area of gardens is decreasing, about $30 \%$ in Wangisagara and about $44 \%$ in Sukapura perceived that the decline had occurred in the past 10 years, but a majority in both villages believed that the decline had been occurring for more than 15years (about 60\% in Wangisagara and about 52\% in Sukapura).

The key informants in Sukapura indicated that the decline was caused by the rapid adoption of modern agricultural practices that provided farmers with the opportunity to gain higher crop yields and income. Various extension programs by government agencies and the introduction of high yielding varieties resulted in a high rate of conversion of bamboo-tree gardens to cash-crop gardens. Sukapura respondents believed that land conversion

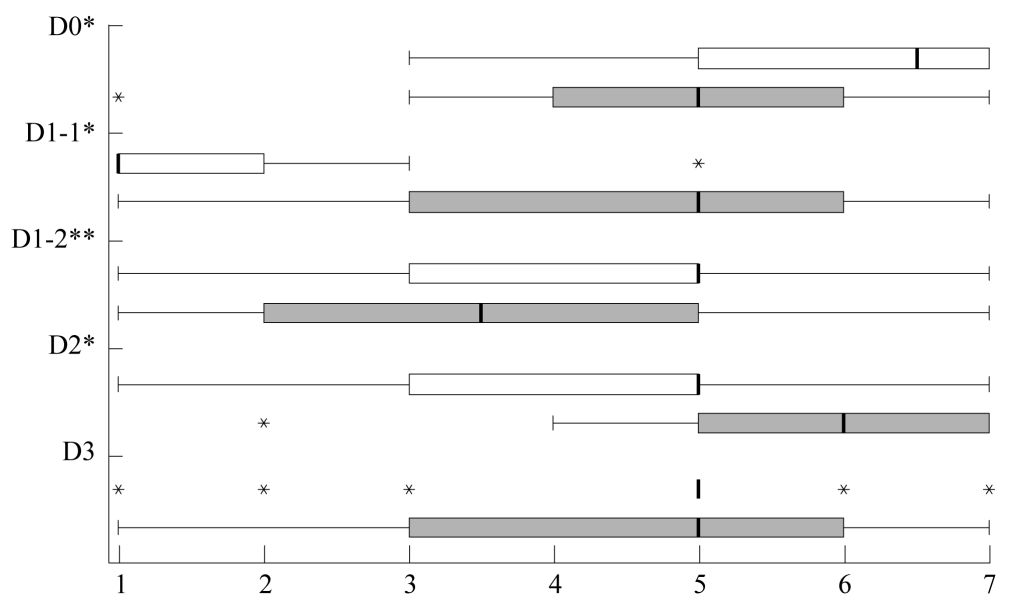

Figure 5. Boxplots of perceptual ranks for the five questions in perceptual category D (bamboo-tree garden decline) for each village: Wangisagara = empty boxes and Sukapura = shaded boxes. Please see Figure 2 for legends and Table 2 for questions. 
had been to cash-crop gardens (D1-1) more than to settlements (D1-2; Figure 5), and their perceptual intensity was significantly higher than that of Wangisagara respondents for D1-1 $(P<0.01)$. The decline in garden area from more than 10 years hence until the time of the survey indicated that the conversion process was still occurring despite the limited extent of bamboo-tree garden patches in the area.

In Wangisagara, the respondents perceived that the gardens were converted to settlements rather than to cash-crop gardens (D1-2 in Figure 5; significantly higher intensity than in Sukapura: $P<0.05$ ). Additionally, the key informants for this village said that the decline was particularly a result of expansion of the industrial sector (mainly the textile industry) and human settlement. The expansion of the textile industry attracted labor from outside the area, leading to an increase in settlers. A few respondents mentioned that conversion to other agricultural systems such as kebun palawija (mix-annual crop garden) had also occurred.

As seen in the responses to question D2, the main perceived causes of the decline in bamboo-tree gardens in the study areas were economic. The respondents of both Wangisagara and Sukapura strongly perceived that they could obtain greater economic benefit from converting their gardens to other agricultural systems or selling them for non-farm uses (Figure 5). In addition, based on our interviews with some informants, converting the bamboo-tree gardens to cashcrop gardens can also provide job and income to the local people. Economic reasons were also the main answer given by ex-owners when asked why they sold their bamboo-tree gardens. In general, the ex-owners had similar perceptions to current owners with regard to the ownership and functions of gardens (i.e. question categories A and B in Table 2).

The respondents in both villages strongly perceived a lack of concern and support from government agencies as a cause of garden decline (D3 in Figure 5; no significant difference between the villages). Replies to a supporting question showed that all respondents, regardless of village, believed that the decline would have been slowed if the government or other institutions supported the garden owners, for example, by giving an insentive to the garden owners who maintained their gardens and by providing good quality seedlings of tree species with high economic value.

\subsubsection{Perceptions on the Existence and Maintenance of Bamboo-Tree Gardens}

Respondents in both villages exhibited strongly positive perceptions that bamboo-tree gardens were still needed (E0 in Figure 6) in the upper Citarum basin, and the intensity was significantly higher in Wangisagara $(P<$ $0.05)$.

Almost all respondents perceived that improving economic returns from the garden, particularly by increasing the market value of the products (E1-2), was a very important step for the future existence of bamboo-tree gardens. However, the intensity of the perception was higher in Wangisagara $(P<0.01$; Figure 6). In addition, respondents from both villages also perceived that the involvement of government and/or other institutions

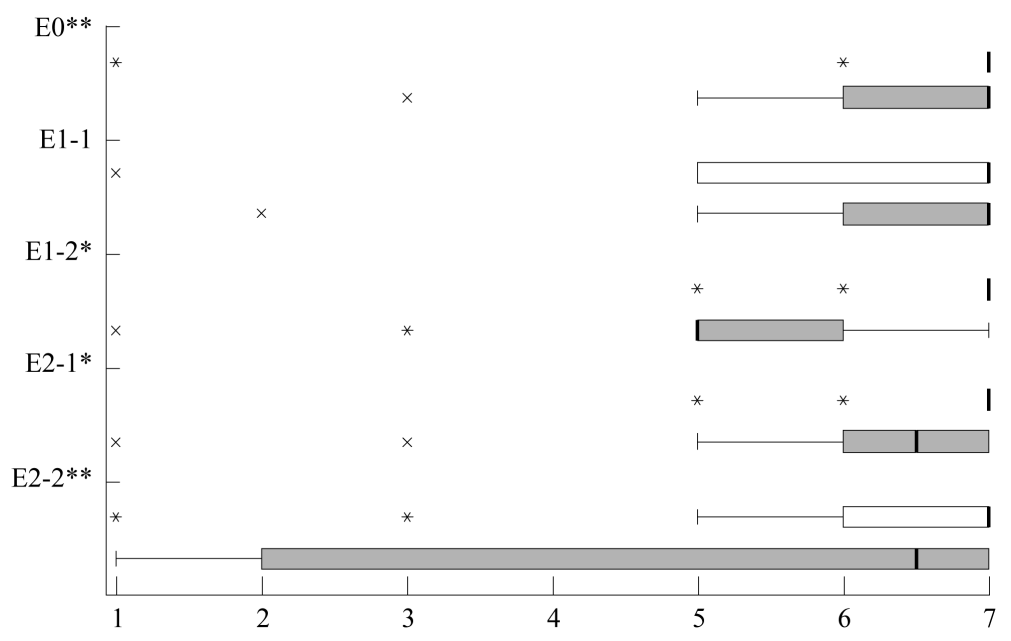

Figure 6. Boxplots of perceptual ranks for the five questions in perceptual category E (importance of bamboo-tree gardens) for each village: Wangisagara $=$ empty boxes and Sukapura $=$ shaded boxes. See Figure 2 for legends and Table 2 for questions. 
would be crucial to improve economic returns (E2-1 and E2-2), and the intensity of these two perceptions was again significantly higher in Wangisagara $(P<0.01$ for E2-1 and $P<0.05$ for E2-2; Figure 6). About $50 \%$ of respondents in Wangisagara answered supporting questions to suggest that they believe that unless economic returns are improved and more support is provided, the conversion of gardens, particularly to settlements, would continue and they would almost certainly disappear from the upper part of the Citarum basin.

\section{Discussion}

\subsection{Functional Aspect of Bamboo-Tree Garden}

Overall, bamboo-tree garden owners in the two study villages have positive perceptions of the socioeconomic, cultural, and ecological roles of the bamboo-tree garden as an element of the landscape. Differences in the intensity of perceptions are influenced by the frame of reference for the perception, such as factual knowledge and emotional experiences [8]. The more coherent the factual knowledge and emotional experiences, the more likely the influence on the perception of people. In general, the bamboo-tree garden owners in Wangisagara have more positive perceptions of the gardens than those of Sukapura. This was seen very clearly in perceptions of the economic function of bamboo-tree gardens; the owners in Sukapura exhibited less positive perceptions. This is because most of the owners in Sukapura village have other, more productive sources of income, for example, vegetable crops. With capital-intensive agricultural practices, they are able to obtain higher incomes than they can from their bamboo-tree garden. Therefore, they consider bamboo-tree gardens not as their primary source of incomeand consequently have a lower intensity of desire to maintain their garden. Bamboo-tree gardens are the least managed type of agricultural land in this landscape (see Wiersum) [15].

The respondents in Sukapura perceived their bamboo-tree gardens as an asset that indicated socioeconomic status but not as a primary source of income. The perceived value of the bamboo-tree garden derives from the land itself or its potential to be converted to a more productive vegetable garden.

The difference in perception intensities between the two villages with regard to the social function of bamboo-tree gardens is presumably related to the local dynamics in livelihoods experienced by the people in the two villages. Although the people in Sukapura are likely to be more market oriented, since capital-intensive agricultural activity is more predominant there than in Wangisagara, they still allow other villagers to freely collect branches, medicinal plants, or raw vegetables for their own use. It is therefore not necessarily the case that engagement in a market-oriented livelihood overrides perceptions of the social function an owner's bamboo-tree garden. Our finding was concomitant to other studies which were carried out by Okubo et al. [16] and Muhamad et al. [19] in other villages in West Java.

The respondents in Sukapura who practice capital-intensive agriculture still retain a sense of community sharing. This finding contrasts with the condition in capital-intensive agricultural practices in developed countries, e.g. Petrzelka [4] mentioned that among conventional farmers in Iowa USA, nature is viewed as a resource to be used and controlled, and farmers usually do not hold a sense of community but see farming primarily as a business. Even though the owners in Wangisagara rejected their garden's social function in terms of providing fuelwood freely for others, but this does not mean that the bamboo-tree gardens in Wangisagara do not have a social function. They limited access for other villagers to collect fuelwood, but they still shared certain products like fruits from their bamboo-tree garden to neighbors as an important part of maintaining social relationships, meaning that the social role of the gardens was to supply excess fruit to villagers.

Respondents in the two study villages exhibited a more or less similar positive perception to the ecological functions of their bamboo-tree garden. Nevertheless, there was some inconsistency between what they perceived to be important and what was actually happening. Despite their perception about the ecological importance of the bamboo-tree garden for the village, such as preventing soil erosion, storing water, and providing habitat for wildlife, the conversion of this land-use type to less environmentally desirable systems was still occurring.

Although no quantitative data estimates have been made on the rate of conversion bamboo-tree gardens, our interviews and visual observations clearly indicate that such conversions continue unabated up to the present time. This suggests that positive perceptions do not always correlate with positive behavior (see also JacksonSmith and Buttel) [20], and sometimes the connection between farmer perception and practice is weak. This is similar to the results of a number of previous studies [4] [6] [7] [21].

In many cases, farmers' practices diverge from their perceptions because the way individual farmers act is not only influenced by their own perceptions but also by cultural and socioeconomic forces and the suitability of the 
bio-physical environment (see also Mekoya et al.; Muhamad et al.) [7] [19]. The development of a strong commitment leading to positive behavior of rural people towards the sustainability of bamboo-tree gardens is essential for their continued existence.

The perceptions of owners of the ecological functions of their bamboo-tree gardens were somewhat in concordance with a study of bird communities in fragmented bamboo-tree gardens reported by Erawan et al. [17] and Parikesit et al. [11]. The diversity of bird species found in bamboo-tree garden patches is presumably related to the structural pattern of vegetation layers and food abundance.

Therefore, ecological concern exhibited by bamboo-tree garden owners is an encouraging sign for conservation efforts. Unfortunately, no other studies concerning the ecological functions of bamboo-tree gardens in the upper Citarum basin have been carried out. It would be important to investigate the role of bamboo-tree gardens as a filter or sink for soil nutrients exported from neighboring cultivated land in the changing agricultural landscape of the Citarum basin. The role of this land-use type in relation to pest outbreaks and predator-prey interactions in vegetable crop gardens are other challenging topics that need to be addressed.

\subsection{Management of the Garden}

Compared with other types of agricultural land (rice fields, vegetable gardens, kebun palawija), bamboo-tree gardens receive the lowest levels of management inputs for production purposes [15]. The number of noncultivated plants, which were found to grow naturally in bamboo-tree gardens including forest species such as Ficus spp., Sterculia oblongata, Arctostaphylos glauca, and Neonauclea lanceolata, was higher than that of domesticated species in both villages (data not shown). Therefore, it is not surprising that the economic productivity of these gardens is lower than that of other agricultural lands.

Management of bamboo-tree gardens without high external energy inputs as practiced by the owners in the two study villages is an example of traditional subsistence agriculture that was presumably predominant in the upper Citarum basin prior to the introduction of capital-intensive agricultural practices in the 1970s.

\subsection{Recognition of Any Decline in Bamboo-Tree Gardens}

There has been an obvious decline in this element in the landscape over the last few decades due to rapid development of modern agricultural practices, particularly in the upper part of the basin (see Parikesit et al.) [11]. Owners displayed a wide awareness that the roots of bamboo clumps are very effective in binding the soil, so severe soil erosion under dense bamboo-tree gardens is unlikely to occur. However, some owners had converted their bamboo-tree gardens to cash crop (vegetables) gardens even though they were located on steep land. This is most conspicuous in Sukapura, where bamboo-tree gardens are usually found in small patches scattered within a matrix of other agroecosystem components such as rice fields and upland cash-crop gardens no larger than a few hectares.

The underlying cause of the decline in bamboo-tree gardens in the upper Citarum basin is clearly economics. Land conversion, population pressure, population growth, and lack of serious effort from the government to conserve bamboo-tree gardens appear to be some by products of these underlying factors. Economic forces are increasingly determining the structure and function of bamboo-tree gardens. When asked to explain certain practices, most respondents focused on pragmatic considerations and concerns about profitability, which were often the overriding factor in decisions regarding land use.

Thus, as pointed out by Corselius et al. [22], many farmers' decisions become more profit-oriented and focused on short-term production. Most of the owners who had already converted their bamboo-tree garden system to cash-crop gardens in Sukapura justified their decisions based on short-term economic viability. It should be noted, however, that farmers do not always, or necessarily ever, make decisions with the sole goal of profit [23] [24]. In concordance with the findings of Lynnne and Rola [25], some farmers in our study argued that income alone is not a significant predictor of conservation behavior; a positive attitude to the environment is also required. However, several other studies suggest that profit motives override environmental motives, even when an awareness of environmental problems exists [19] [26] [27].

Farmers responding to market demand and obtaining short-term benefits through such behavior has not come without environmental cost within the agricultural landscape of the upper Citarum basin. The decline in bamboo-tree gardens due to land conversion to capital-intensive agriculture has changed the landscape structure [11]. 
The conversion of bamboo-tree gardens to vegetable gardens has undoubtedly caused a loss of habitat for various wild animals that use bamboo-tree gardens but not vegetable gardens. The conversion will ultimately cause a homogenization of the landscape structure [28] and loss of diversity of the agroecosystem of the upper Citarum basin. The use of pesticides in vegetable gardens may further contribute to environmental pollution [11] [29] [30].

The perception of owners that continuing economic pressure threatens the future existence of bamboo-tree garden is entirely rational. The results of our study show that the economic pressures are clearly leading to conversion of bamboo-tree gardens to other land uses, whereas we are not aware of any concerted efforts to preserve this traditional agricultural system. Various levels of government emphasize on production rather than searching for a balance between production and conservation of traditional agroecosystems [28]. Bamboo-tree gardens may soon be confined to small patches occupying steep, non-arable parts of the Citarum basin [11].

The finding that there is not always a direct correlation between human perception and action is in line with that of Mekoya et al. [7]. But gaining an understanding of human perceptions could still be an important step in revitalizing traditional bamboo-tree gardens because only through understanding of human perceptions can the interaction between the social system and the agroecosystem be shaped [3].

\subsection{The Outlook for Preservation of the Gardens}

The tradition of maintaining bamboo-tree gardens as an important family asset offers opportunities with respect to the objectives of conserving biodiversity and maintaining the socioeconomic role of this land-use type in the local production system. The owners certainly exhibit some desire to maintain the existing bamboo-tree garden patches in the study area, but this alone does not assure the future existence of bamboo-tree gardens in the upper Citarum basin. Support from government and other agencies through incentive-oriented programs that can act against pure market economic forces are needed. An example of such incentives might be to make payments to the owners of bamboo-tree gardens for the environmental services provided by maintaining this land use [31] [32].

Ideally, efforts to conserve bamboo-tree gardens should be undertaken throughout the entire upper Citarum basin. However, the present study indicates that conservation efforts are likely to be much more challenging in the uppermost part of the basin in villages such as Sukapura. In this area, the local people, bamboo-tree garden owners in particular, have long been subject to a market-oriented livelihood (i.e. capital-intensive agricultural practices). Therefore, conservation efforts need to be directed toward improving the economic value of bambootree garden products and at the same time improving the ecological function of this landuse type.

\section{Conclusions}

1) The owners of bamboo-tree gardens in the two study villages perceive that the gardens still represent an important symbol of their socioeconomic status and are associated with a tradition of inheritance.

2) In general, the owners in Wangisagara exhibit more positive perceptions of bamboo-tree garden management and conservation than those in Sukapura.

3) Although there is not always a direct correlation between perception and behavior in relation to bambootree garden management, an understanding of human perceptions in this area provides insight into the likely success of any initiatives that can be taken to revitalize or conserve bamboo-tree gardens. The clearest example of this is that because the villagers retain a strong cultural perception of the heritage value of the bamboo- tree gardens, they will likely be very responsive to conservation efforts that increase the economic value of the gardens and reduce the opportunity cost of not converting them to more intensive production or other land uses.

4) Efforts to conserve bamboo-tree gardens will be more challenging in Sukapura than in Wangisagara due to stronger market-oriented sources of livelihood in Sukapura.

5) If improvement of the economic conditions surrounding bamboo-tree gardens does not occur, the eventual disappearance of this agroecosystem element from the upper Citarum basin is almost inevitable.

\section{Acknowledgements}

This study was funded by the Institute of Ecology, Padjadjaran University. Additional data was funded by the Faculty of Social and Political Sciences, Padjadjaran University. The principle author thanks his students for 
their assistance during the fieldwork.

\section{References}

[1] Nassauer, J.I. and Westmacott, R. (1987) Progressiveness among Farmers as a Factor in Heterogeneity of Farmed Landscapes. In: Turner, M.G., Ed., Landscape Heterogeneity and Disturbance, Springer, New York, 199-210. http://dx.doi.org/10.1007/978-1-4612-4742-5_11

[2] Garcia-Llorente, M., Martin-Lopez, B., Gonzales, J.A., Alcorlo, P. and Montes, C. (2008) Social Perceptions of the Impacts and Benefits of Invansive Alien Species: Implications for Management. Biological Conservation, 141, 29692983. http://dx.doi.org/10.1016/j.biocon.2008.09.003

[3] Marten, G.G. (2001) Human Ecology: Basic Concept for Sustainable Development. Earthscan Publications, London, 256.

[4] Petrzelska, P., Korsching, P.F. and Malia, J.E. (1996) Farmers’ Attitudes and Behavior toward Sustainable Agriculture. The Journal of Environmental Education, 28, 38-44. http://dx.doi.org/10.1080/00958964.1996.9942814

[5] Uri, N.D. (2000) Perceptions on the Use of No-Till Farming in Production Agriculture in the United States: An Analysis of Survey Results. Agriculture, Ecosystems and Environment, 77, 263-266. http://dx.doi.org/10.1016/S0167-8809(99)00085-7

[6] Tahvanainen, L., Tyrvainen, L., Ihalainen, M., Vuorela, N. and Kolehmainen, O. (2001) Forest Management and Public Perceptions: Visual versus Verbal Information. Landscape and Urban Planning, 53, 53-70. http://dx.doi.org/10.1016/S0169-2046(00)00137-7

[7] Mekoya, A., Oosting, J., Fernandez-Rivera, S. and Van der Zijpp, J. (2008) Farmers’ Perceptions about Exotic Multipurpose Fodder Trees and Constraints to Their Adoption. Agroforestry System, 73, 141-153. http://dx.doi.org/10.1007/s10457-007-9102-5

[8] Boogaard, B.K, Oosting, S.J. and Bock, B.B. (2006) Elements of Societal Perception of Farm Animal Welfare: A Quantitative Study in the Netherlands. Livestock Science, 104, 13-22. http://dx.doi.org/10.1016/j.livsci.2006.02.010

[9] Parikesit (2004) Local Bioresources Assessment in the Agricultural Landscape of the Upper Citarum Watershed, Indonesia. PhD Dissertation, University of Tokyo, Tokyo.

[10] Parikesit, Djuniwarti and Hadikusumah, H.Y. (1997) Spatial Structure and Floristic Diversity of Man-Made Ecosystems in Upper Citarum River Basin. In: Dove, M.R. and Sajise, P.E., Eds., The Conditions of Biodiversity Maintenance in Asia, East-West Center, Honolulu-Hawaii, 17-43.

[11] Parikesit, Takeuchi, K., Tsunekawa, A. and Abdoellah, O.S. (2004) Kebon Tatangkalan: A Disappearing Agroforest in the Upper Citarum Watershed, West Java, Indonesia. Agroforestry Systems, 63, 171-182. http://dx.doi.org/10.1007/s10457-004-1182-x

[12] Soemarwoto, O. and Soemarwoto, I. (1984) The Javanese Rural Ecosystem. In: Rambo, A.T. and Sajise, P.E., Eds., An Introduction to Human Ecology Research on Agricultural System in Southeast Asia, University of the Philippines Los Banõs, Laguna, 254-287.

[13] Christanty, L., Mailly, D. and Kimmins, J.P. (1996) “Without Bamboo, the Land Dies”: Biomass, Litterfall, and Soil Organic Matter Dynamics of a Javanese Bamboo-Talun-Kebunsystem. Forest Ecology and Management, 87, 75-88. http://dx.doi.org/10.1016/S0378-1127(96)03834-0

[14] Michon, D. and Mary, F. (1994) Conversion of Traditional Village Gardens and New Economic Strategies of Rural Households in the Area of Bogor, Indonesia. Agroforestry Systems, 25, 31-58. http://dx.doi.org/10.1007/BF00705705

[15] Wiersum, K.F. (2004) Forest Gardens as an "Intermediate” Land Use System in the Nature-Culture Continuum: Characteristics and Future Potential. Agroforestry Systems, 61, 123-134. http://dx.doi.org/10.1007/978-94-017-2424-1 9

[16] Okubo, S., Parikesit., Harashina, K., Muhamad, D., Abdoellah, O.S. and Takeuchi, K. (2010) Traditional Perennial Crop-Based Agroforestry in West Java: The Trade off between On-Farm Biodiversity and Income. Agroforestry Systems, 80, 17-31. http://dx.doi.org/10.1007/s10457-010-9341-8

[17] Erawan, T.S., Djuangsih, N., Muchtar, M., Setiana, H. and Istanti, L.S. (1997) Community Structure and Diversity of Fauna in Upper Citarum River Basin, West Java, Indonesia. In: Dove, M.R. and Sajise, P.E., Eds., The Conditions of Biodiversity Maintenance in Asia, East-West Center, Hawaii, 73-111.

[18] Lynch, F., Hollnsteiner, M.R. and Corvar, L.C. (1974) Data Gathering by Social Survey. Trial Edition. Social Science Council Inc., Quezon City, 272 p.

[19] Muhamad, D., Okubo, S., Harashina, K., Parikesit, Gunawan, B. and Takeuchi, K. (2014) Living Close to Forests Enhances People's Perception of Ecosystem Services in Forest-Agricultural Landscape of West Java, Indonesia. Ecosystem Services, 8, 197-206. http://dx.doi.org/10.1016/j.ecoser.2014.04.003 
[20] Jackson-Smith, D. and Buttel, F. (1998) The Conventional Alternative Agricultural Paradigm: A Replication. Paper Prepared for the Rural Sociological Society Meeting, Portland, 5-9 August 1998.

[21] Beedell, J. and Rehman, T. (2000) Using Social-Psychology Models to Understand Farmers' Conservation Behavior. Journal of Rural Studies, 16, 117-127. http://dx.doi.org/10.1016/S0743-0167(99)00043-1

[22] Corselius, K.L., Simmon, S.R. and Flora, C.B. (2003) Farmer Perspectives on Cropping Systems Diversification in Northwestern Minnesota. Agricultural and Human Values, 20, 371-383. http://dx.doi.org/10.1023/B:AHUM.0000005148.00229.70

[23] Anosike, N. and Coughenour, M.C. (1990) The Socio-Economic Basis of Farm Enterprise Diversification Decisions. Journal Rural Sociology, 55, 1-24. http://dx.doi.org/10.1111/j.1549-0831.1990.tb00670.x

[24] Turvey, C. (1991) Environmental Quality Constraints and Farm-Level Decision Making. American Journal of Agricultural Economics, 73, 1404-1405. http://dx.doi.org/10.2307/1242390

[25] Lynne, G.D. and Rola L.R. (1988) Improving Attitude-Behavior Prediction Models with Economic Variables: Farmers’ Action toward Soil Conservation. Journal of Social Psychology, 128, 19-28. http://dx.doi.org/10.1080/00224545.1988.9711680

[26] Carr, S. and Tait, J. (1991) Differences in the Attitudes of Farmers and Conservationists and Their Implications. Journal of Environmental Management, 32, 281-294. http://dx.doi.org/10.1016/S0301-4797(05)80058-1

[27] Willock, J., Deary, I.J., McGregor, M.M., Sutherland, A., Edwards-Jones, G. and Morgan, O. (1999) Farmers’ Attitudes, Objectives, Behavior and Personality Traits: The Edinburgh Study of Decision Making on Farms. Journal of Vocational Behavior, 54, 5-36. http://dx.doi.org/10.1006/jvbe.1998.1642

[28] Gunawan, B., Parikesit and Abdoellah, O.S. (2005) Micro Level Implications for Macro Level Policy: A Case Study of Conservation in the Upper Citarum River Basin, West Java. In: Dove, M.R., Sajise, P.E. and Doolittle, A.A., Eds., Conserving Nature in Culture: Case Studies from Southeast Asia, Yale Southeast Asia Studies Monographs 54, Yale Southeast Asia Studies, New Haven, 119-143.

[29] Abdoellah, O.S., Hadikusumah, H.Y., Takeuchi, K., Okubo, S. and Parikesit (2006) Commercialization of Homegardens in an Indonesia Village: Vegetation Composition and Functional Changes. Agroforestry Systems, 68, 1-13. http://dx.doi.org/10.1007/s10457-005-7475-X

[30] Nautiyal, S., Kaechele, H., Rao, K.S., Maikhuri, R.K. and Saxena, K.G. (2007) Energy and Economic Analysis of Traditional versus Introduced Crops Cultivation in the Mountains of the Indian Himalayas: A Case Study. Energy, 32, 2321-2335. http://dx.doi.org/10.1016/j.energy.2007.07.011

[31] Pagiola, S. (2008) Payments for Environmental Services in Costa Rica. Ecological Economics, 65, 712-724. http://dx.doi.org/10.1016/j.ecolecon.2007.07.033

[32] Wunscher, T., Engel, S. and Wunder, S. (2008) Spatial Targeting of Payments For Environmental Services: A Tool for Boosting Conservation Benefits. Ecological Economics, 65, 822-833. http://dx.doi.org/10.1016/j.ecolecon.2007.11.014 